\title{
Historia przeszczepiania szpiku w Polsce
}

\author{
Rafał Machowicz
}

Celem artykułu jest przedstawienie historii przeszczepiania szpiku w Polsce. Okazją do jej przypomnienia jest zbliżająca się 30 rocznica pierwszego allogenicznego przeszczepienia szpiku w Polsce przez prof. Wiesława W. Jędrzejczaka (28 listopada 1984). Szczególny nacisk położono na analizę pierwszych prób podejmowanych przez prof. Jana Raszka (od 1938 we Lwowie) i prof. Zofię Migdalską-Romaniuk (od lat pięćdziesiątych w Warszawie). Zaprezentowano najistotniejsze kroki w rozwoju współczesnej polskiej transplantologii w zakresie przeszczepiania komórek krwiotwórczych, przedstawiono także aktualny stan tego leczenia w Polsce.

\section{History of bone marrow transplantation in Poland}

The aim of this manuscript is to present the history of bone marrow transplantation in Poland in the advent of the 30 th anniversary of the first successful allogenic bone marrow transplantation. This was performed on $28^{\text {th }}$ November 1984 by prof. Wiesław Wiktor-Jędrzejczak. The first attempts were made by prof. Jan Raszek (from 1938 in Lwow) and prof. Zofia Migdalska-Romaniuk (from 1950s in Warsaw). These are analysed. The most important steps in the development of modern Polish transplantology in terms of the haematopoietic stem cell transplantation are acknowledged. The current status of this therapy in Poland is also described.

NOWOTWORY Journal of Oncology 2014; 64, 5: 460-465

Słowa kluczowe: przeszczepianie szpiku, historia medycyny

Key words: bone marrow transplantation, history of medicine

\section{Wstęp}

W przededniu trzydziestej rocznicy pierwszego allogenicznego przeszczepienia szpiku kostnego w Polsce, wykonanego 28 listopada 1984 roku przez zespół pod kierunkiem prof. Wiesława W. Jędrzejczaka, artykuł ten przybliża historię rozwoju nauki, który umożliwił ten sukces, oraz przedstawia go w kontekście poprzednich prób i obecnego rozwoju transplantologii. Jest to także próba krytycznej analizy wcześniejszych prób przeszczepiania szpiku kostnego w Polsce, starająca się, uwzględniając kontekst historyczny, przedstawić ówczesne działania w świetle obecnej wiedzy.

\section{Tło historyczne}

Od zarania dziejów krew była uważana za źródło siły i życia. Galen odkrył, że żyły i tętnice transportują krew, a nie
- jak sądzono - powietrze. Jego teoria humoralna spowodowała, iż w celu przywrócenia zaburzonej równowagi organizmu dokonywano krwioupustów. Opisanie krążenia krwi przez Williama Harveya w 1616 roku dostarczyło podwalin pod dożylne podawanie substancji mających poprawić stan chorego. Stan ówczesnej wiedzy podsumowuje Johann Daniel Major w swym dziele Chirurgia Infusoria z 1667 roku [1]. Opisuje przetoczenia krwi, a także substancji odżywczych - bulionu, mleka czy wina (co można uznać za początki nie tylko transfuzjologii, ale i żywienia pozajelitowego). Próby te nie mogły być bezpieczne ze względu na brak aseptyki, ale przede wszystkim z powodu braku znajomości grup krwi oraz wykonywania przetoczeń obcogatunkowych (uważano na przykład, że krew jagnięcia będzie miała zbawienny wpływ na osobę porywczą). Pacjen- 


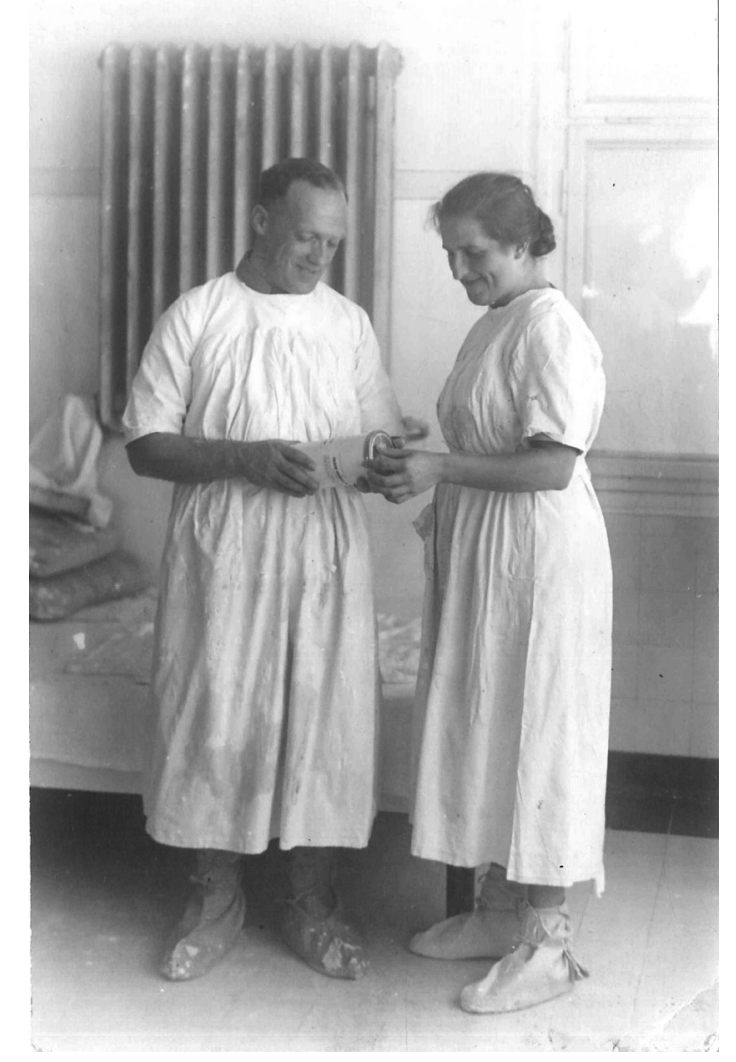

Rycina 1. Profesor Jan Raszek (Rosenbusch) podczas pracy w Klinice

tów ratowały względnie niewielka ilość przetaczanej krwi oraz przypadkowe natrafienie na krew zgodną grupowo. Odkrycie grup krwi przez Landsteinera w 1900 roku zapoczątkowało rozwój współczesnej transfuzjologii.

W tym czasie kolejnym krokiem milowym stało się opracowanie techniki biopsji szpiku. Początkowo pobierano go z nasad kości piszczelowej (Pianese 1903) i udowej (Ghedini 1908). Jako pierwszy próbki z mostka pobierał Seyfarth w 1922 [2], a metodę biopsji aspiracyjnej z mostka, która pozwoliła na upowszechnienie tego typu diagnostyki, opisał Arinkin w 1929 r. [3]. Pomimo, że miednica zawiera około 50\% szpiku kostnego, jej nakłucie zaczęto brać pod uwagę dopiero w latach 50. [4]. Obecnie standardowym miejscem pobierania trepanobiopsji, szpiku od dawców oraz często także biopsji aspiracyjnych jest okolica kolca biodrowego tylnego górnego.

\section{Pierwsze próby}

Pierwsze w Polsce (i prawdopodobnie na świecie) próby przeszczepienia szpiku podjął w 1938 roku Jan Rosenbusch (ryc. 1) - asystent w Klinice Pediatrii Uniwersytetu Jana Kazimierza we Lwowie, kierowanej przez prof. Franciszka Groera. Inspiracją była informacja o możliwości doszpikowego podawania leków. Badacze zakładali, iż szpik kostny produkuje lub przechowuje nieznane im czynniki biologiczne odpo-

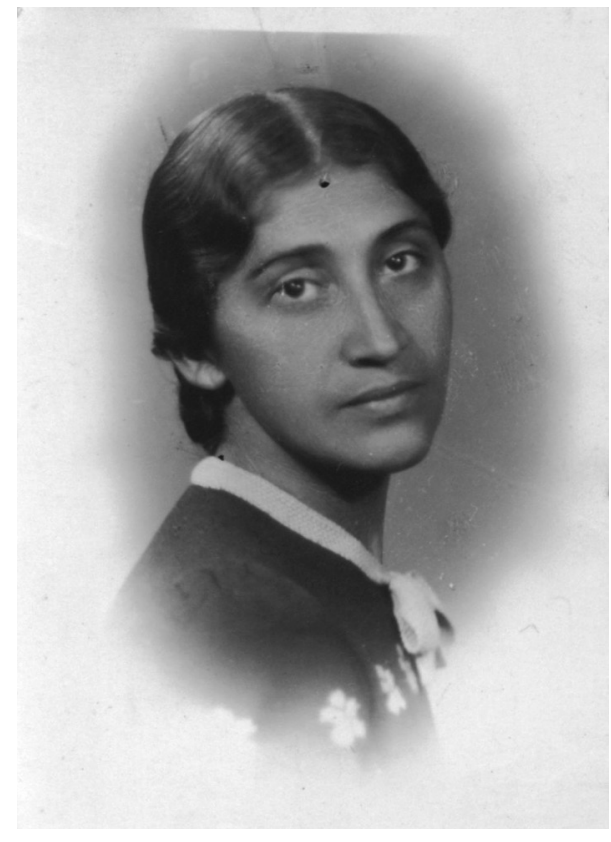

Rycina 2. Profesor Zofia Migdalska-Romaniuk (Archiwum WUM)

wiedzialne za strukturę i prawidłowe funkcjonowanie układu hematopoezy. Zastosowali więc terapię substytucyjną: bezpośredni transfer szpiku od zdrowego dawcy do pacjenta. Pierwsze eksperymenty były prowadzone na królikach, a technika samego nakłucia była doskonalona na zwłokach dzieci. Podczas zabiegu biorca i dawca leżeli równolegle na dwu stołach. Miejscem pobrania, jak i podawania szpiku był mostek (w linii pośrodkowej, pomiędzy przyczepami 3. i 4. żebra) [4]. Podczas biopsji szpiku stosowano znieczulenie miejscowe, co nie było w owych czasach standardem. Zzachowaniem aseptyki przetaczano kilkanaście mililitrów szpiku. Jego podawanie jest opisywane jako „,nieco bolesne”, obserwowano także czasami przejściowy obrzęk w miejscu podania. Podczas doboru dawcy kierowano się doświadczeniem krwiodawstwa - dorosły (20-40 lat), zdrowy, zgodny pod względem grupy krwi ABO i Rh. Wykonywano także próbę zgodności i dbano o kontrolę jakości — badano rozmaz pozostałości przeszczepianego szpiku.

W czasie wojny Jan Rosenbusch zmienił nazwisko na Raszek.W sierpniu 1949 r. opublikował powyższą procedurę w Annales Pediatrici, wydawanych w Bazylei.

W latach pięćdziesiątych w Klinice Pediatrii Akademii Medycznej w Warszawie próby przeszczepiania szpiku prowadziła Zofia Migdalska-Romaniuk (ryc. 2). To eksperymentalne leczenie wydaje się być kontynuacją działalności Jana Raszka - dawca zgodny z regułami krwiodawstwa, bezpośrednie przetaczanie ok. 5-10 ml szpiku. Najistotniejsze różnice to brak antykoagulantu w strzykawce (aby nie zmienić właściwości szpiku) oraz miejsce podania — oprócz mostka także grzebień kości biodrowej. Zofia Migdalska-Romaniuk 
cytuje jego wyniki, ale w bardzo zaskakujący sposób: „Z badaczy polskich J. Raszek-Rozenbuch z Kliniki F. Groëra (1938) zapoczątkowała (sic!) badania nad przeszczepianiem szpiku. Próbowała ona - z zachęcającymi wynikami — leczyć białaczkę limfatyczną i chorobę Addisona-Biermera u dzieci"[5]. Sugeruje to, że nie znała Raszka, ale sądziła, że jest on kobietą posługującą się podwójnym nazwiskiem. Natomiast występujący w zacytowanym fragmencie błąd w nazwisku jest zapewne częściowo literówką, gdyż w piśmiennictwie artykułu podana jest bardziej prawidłowa wersja (Rozenbusch). Na uwagę zasługuje fakt, że Jan Raszek pracował wówczas w Warszawie, w znajdującym się w odległości zaledwie kilku kilometrów Instytucie Matki i Dziecka (którego dyrektorem był prof. Groer). Jan Raszek nie kontynuował już przeszczepiania szpiku, ograniczając się jedynie do opublikowania wcześniejszych wyników. Potwierdzają to dwie pracujące w tamtych czasach w Instytucie lekarki (dr Maria Steyer i prof. Barbara Cabalska), z którymi autor skontaktował się, aby spróbować wyjaśnić sprawę pomyłki w cytowaniu. Wich relacjach nie było wówczas ożywionej współpracy naukowej miedzy ośrodkami w dzisiejszym rozumieniu tego słowa (wspólne badania czy choćby zjazdy lub konferencje). Istniały natomiast w pewnym stopniu kontakty kliniczne - jak chociażby przekierowywanie nowych pacjentów przy braku miejsca w danym ośrodku. Zofia Migdalska-Romaniuk najprawdopodobniej zdawała sobie sprawę, że prof. Raszek jest kierownikiem Kliniki Pediatrii IMiD. Podwójne nazwisko autora zmyliło ją jednak do tego stopnia, iż sądziła, że ma do czynienia z inną osobą, zwłaszcza, że Jan Raszek nie był wówczas łączony z przeszczepianiem szpiku. Można więc z dużą dozą pewności stwierdzić, że jej wiedza o pracach Jana Raszka opierała się jedynie na publikacjach i (przynajmniej do 1955 r.) nie miała miejsca bezpośrednia wymiana doświadczeń. Jest to istotna informacja dla historii polskiej transplantologii, gdyż często Zofia Migdalska-Romaniuk bywa przedstawiana jako bezpośrednia kontynuatorka prac Jana Raszka.

Dziś wiemy, że stosowane przez Jana Raszka i Zofię Migdalską-Romaniuk bezpośrednie przetaczanie szpiku nie miało szans na powodzenie. Konieczne jest kondycjonowanie, które całkowicie lub częściowo (RIC — Reduced Intensity Conditioning) niszczy poprzedni układ odpornościowy — bez tego przygotowania zniszczeniu ulegnie podany szpik. Badacze także nie zdawali sobie jeszcze sprawy z konieczności doboru w zakresie antygenów zgodności tkankowej (HLA), co również uniemożliwiało skuteczne przeszczepienie. Gdy szpik pochodził od rodziców, były to swego rodzaju (jedynie z nazwy) przeszczepy haploidentyczne. Dobór w zakresie grupy krwi, obecnie niebędący przeszkodą, miał wtedy duże znaczenie: bezpośrednie podanie niedobranego grupowo szpiku prowadzić mogło do powikłań takich jak przy transfuzji niezgodnej krwi, zwłaszcza że szpik podawano wielokrotnie. Objętość podawanego szpiku — ok. $10 \mathrm{ml}$, nawet jeśli była powtarzana i stosowana u dzieci, jest bardzo niewielka (z drugiej strony mogło to uchronić przed cięższymi komplikacjami zabiegu). Przy tych wszystkich fundamentalnych brakach przeszczepiony szpik nie mógł podjąć funkcji. Czym zatem można tłumaczyć pozytywny efekt zastosowania tej nietypowej procedury u niektórych opisywanych pacjentów?

Jan Raszek osiągał najlepsze wyniki u chorych na niedokrwistość Addisona-Biermera i lymphadenosis aleukemica. $W$ jego czasach nie znano jeszcze witaminy $B_{12}$ (została odkryta w 1948 r.). W latach 20. zaobserwowano poprawę u psów karmionych surową wątrobą. Terapia opierała się więc na spożywaniu dużych ilości surowej wątroby (nawet 300-500 g dziennie) lub przygotowanych z niej wyciągów (także podawanych parenteralnie). Opisywana 13-letnia pacjentka podczas dwu hospitalizacji w 1939 r. uzyskała dobrą odpowiedź na tego typu leczenie. Z kolejnym ciężkim nawrotem zgłosiła się we wrześniu 1940 r. kilka miesięcy po — jak opisuje Raszek — „odstawieniu wątroby”. Prawdopodobnie w warunkach okupacji nie było możliwości uzyskania znacznych ilości wątroby. Tym razem dostawała preparat campolon, będący oczyszczonym ekstraktem wątroby podawanym domięśniowo, o skuteczniejszym przyswajaniu niż poprzednio stosowane (droga podania była ważna u tej pacjentki ze względu na opisywaną achlorhydrię, wiążącą się zapewne z zaburzeniami powodującymi upośledzenie wchłaniania witaminy $\mathrm{B}_{12}$ z przewodu pokarmowego). Przy miernej odpowiedzi po 7 tygodniach terapii Raszek zdecydował się na przeszczepienie $10 \mathrm{ml}$ szpiku. Jak podaje, w ciągu 24 godzin stan pacjentki znacznie się poprawił, po tygodniu zastosowano kolejne przeszczepienie, i pacjentka w dobrym stanie opuściła szpital. W tym opisie ogniskują się możliwe przyczyny pozytywnego efektu: stosowana inna, skuteczna terapia, której działanie zbiegło się w czasie (witamina $B_{12}$ ), lepsze odżywienie pacjenta w szpitalu (w czasie wojny), silny efekt placebo (nowa lecznicza procedura). Być może istnieje możliwość, że podany szpik uwolnił substancje (cytokiny, składniki DNA, witaminę $B_{12}$ ) mogące w pewnym, niewielkim stopniu wesprzeć funkcję szpiku (?). Byłby to jednak efekt krótkotrwały i najprawdopodobniej o tak małym natężeniu, że niemożliwy do zaobserwowania.

Inną jednostką chorobową, w której Raszek osiągał zachęcające wyniki, była lymphadenosis aleukaemica — wyróżniany wówczas podtyp ostrej białaczki limfatycznej charakteryzujący się powiększeniem węzłów chłonnych ze względną limfocytozą (bez leukocytozy) we krwi obwodowej [6]. Nie można wykluczyć, że niektórzy z tak diagnozowanych pacjentów mieli np. infekcje wirusowe powikłane nadkażeniem bakteryjnym o bardzo ciężkim przebiegu, wiążące się z leukopenią i względną limfocytozą (nie było wówczas antybiotyków). Opanowanie ostrej białaczki przy braku jakiejkolwiek chemioterapii nie wydaje się możliwe (działalność Sidneya Farbera — „ojca chemioterapii" — to 
dopiero druga połowa lat 40. w USA). Wątpliwości co do diagnozy nowotworu budzi także przypadek 14-letniego chłopca, który dzięki 20 transfuzjom szpiku osiągnął trwałą remisję (a następnie ukończył Cambridge). Trudno jest określić, czy powtarzane zabiegi mogły mieć (np. dzięki swoistej immunomodulacji) jakikolwiek korzystny efekt, czy raczej nie przeszkodziły one w wyzdrowieniu dzięki siłom organizmu.

Zofia Migdalska-Romaniuk prowadziła swoje leczenie eksperymentalne kilkanaście lat później niż Jan Raszek, stąd większe możliwości terapeutyczne - stosowanie witaminy $\mathrm{B}_{12}$, pierwszej chemioterapii, czy antybiotyków. Najlepsze efekty osiągała ona w leczeniu choroby Werlhofa, czyli autoimmunizacyjnej plamicy małopłytkowej. Choroba ta jest związana z powstaniem przeciwciał przeciwko płytkom krwi, które powodują ich usuwanie w śledzionie, co w efekcie może prowadzić do objawowej skazy małopłytkowej. Podanie szpiku mogłoby hipotetycznie u niektórych pacjentów spowodować niejako„,odwrócenie uwagi" układu odpornościowego, skupiającego się na nowym celu, i w ten sposób zmniejszyć natężenie objawów. Kluczem jednak do powodzenia tych zabiegów wydaje się być, oprócz silnego efektu placebo, naturalny przebieg schorzenia. U około 50-70\% dzieci w ciągu 6 miesięcy dochodzi do samoistnej remisji [7]. Zofia Migdalska-Romaniuk, oceniając efekty tej terapii u 68 pacjentów, odstąpiła w 1967 r. od dalszych przeszczepień [8]. W tych badaniach zabrakło randomizacji i grupy kontrolnej. Przy stosowanej procedurze zaślepienie badania byłoby trudne i nie do końca etyczne (np. bolesne nakłuwanie mostka, aby podać, zamiast szpiku, sól fizjologiczną). Braki te nie powinny być jednak uznawane za niedopatrzenie badaczy, gdyż było to na długo przed erą Evidence-based medicine (EBM).

Nie można mieć pretensji do Jana Raszka czy Zofii Migdalskiej-Romaniuk, że nie przekroczyli ograniczeń swojej epoki i nie odkryli typowania HLA oraz kondycjonowania, przez co opracowana przez nich metoda skazana była na niepowodzenie. Warto podkreślić ich innowacyjność i chęć pomocy pacjentom. Ich niezwykle celne spostrzeżenia pokazują wspaniałą intuicję i potwierdzają się po dziś dzień. Jan Raszek postulował istnienie w szpiku "haematopoietic principle ${ }_{, \prime \prime}$ zasady krwiotwórczej" (tłum własne, oryg. artykuł w j. ang.), która znajduje się tam w większej niż niezbędna ilości i może być przeniesiona do innego organizmu. Było to na długo przed odkryciem komórek macierzystych. Zofia Migdalska-Romaniuk, kończąc swój artykuł, podkreśla potrzebę badania losów przeszczepionego szpiku (dzisiejsze badania chimeryzmu) oraz już w 1955 przewidziała konieczność rozwoju i prawnego unormowania „szpikodawstwa”.

\section{Sukces}

Rozwój współczesnych technik transplantacji miał miejsce w ośrodkach amerykańskich (E. D. Thomas) i francuskich
(G. Mathé). Korzystając z doświadczeń z regeneracją układu krwiotwórczego po wysokich dawkach promieniowania u zwierząt, jako pierwsze kondycjonowanie zastosowano napromienianie całego ciała. Przeszczepienie syngeniczne (od bliźniaka jednojajowego) było możliwe już w roku 1957 [9], ale dopiero prace nad doborem w zakresie odkrytego w 1958 r. układu HLA [10] umożliwiły przeszczepienia allogeniczne w roku 1965 [11]. Stopniowo udoskonalano opiekę okołoprzeszczepową, w tym zagadnienia związane z chorobą przeszczep przeciwko gospodarzowi. Śmiertelność w pierwszych dekadach była bardzo wysoka - w przeprowadzonym w 1977 r. podsumowaniu 100 zabiegów, pomimo przyjęcia się przeszczepu u 93, ponad rok bez wznowy choroby przeżyło zaledwie 13 pacjentów [12].

W Polsce w 1983 r. nieudaną próbę przeszczepienia syngenicznego u chorej na anemię aplastyczną podjął ośrodek poznański (prof. Urszula Radwańska).

Pierwszy (i pierwszy udany) zabieg przeszczepienia allogenicznego przeprowadził 28 listopada 1984 prof. Wiesław Wiktor Jędrzejczak wraz z Zespołem Przeszczepiania Komórek Krwiotwórczych Zakładu Immunologii i Klinicznego Oddziału Izotopowego Centralnego Szpitala Klinicznego Wojskowej Akademii Medycznej w Warszawie. Sześcioletnia dziewczynka, u której w wieku 5 miesięcy rozpoznano niedokrwistość Diamonda-Blackfana, otrzymała szpik od swojej zgodnej w zakresie HLA (I klasy) i niereagującej w mieszanej hodowli limfocytów siostry [13]. Ryzyko zabiegu zwiększała znaczna hemosyderoza, występująca u pacjentki po kilkudziesięciu transfuzjach koncentratu krwinek czerwonych. Był to drugi na świecie zabieg w tej chorobie, jest ona najdłużej żyjącym pacjentem, a zastosowany po raz pierwszy busulfan z cyklofosfamidem stał się standardem kondycjonowania w tym rozpoznaniu.

Bardzo ważne są, odmienne od dzisiejszych, okoliczności, w jakich rozpoczęto przeszczepianie szpiku. Obecnie, gdy wprowadzana jest nowa metoda terapeutyczna, polscy lekarze mają możliwość nauczenia się techniki podczas wizyt w zagranicznym ośrodku, a niezbędny specjalistyczny sprzęt jest $w$ razie potrzeby sprowadzany. $Z$ powodu braku możliwości wymiany zagranicznej, która miała miejsce po wprowadzeniu stanu wojennego, cała technologia związana z przeszczepianiem szpiku musiała zostać stworzona „od zera", opierając się jednie na wskazówkach zawartych w publikacjach [8]. Opracowane przez zespół pod kierunkiem prof. Wiesława W. Jędrzejczaka instrumentarium i procedury nie tylko pozwoliły na skuteczne przeprowadzenie przeszczepienia, ale wyznaczały nowe standardy postępowania - pobrany szpik znajdował się cały czas w zamkniętym układzie, podczas gdy w stosowanej ówcześnie metodzie miał kontakt z powietrzem.

Sukces był możliwy dzięki skrupulatnemu przygotowaniu, a także dzięki wielu wcześniejszym eksperymentom z zakresu nauk podstawowych, dotyczących m.in. mini- 
malnej liczby przeszczepianych komórek, pozwalającej na wyleczenie anemii u myszy W/Wv [14]. Jan Raszek, a następnie Zofia Migdalska-Romaniuk przetaczali jednorazowo ok. $10 \mathrm{ml}$ szpiku. Objętość ta nie opierała się na podstawach naukowych, a na względach czysto praktycznych - taką ilość szpiku można było względnie łatwo uzyskać i dawała się ona wtłoczyć w mostek biorcy. Po zastosowaniu mieloablacyjnego kondycjonowania nie ma miejsca na dowolność - podanie niewystarczającej liczby komórek macierzystych prowadzi do braku odnowy hematopoezy i śmierci. Nie było możliwości pobrania dowolnie dużej ilości szpiku, gdyż dawczynią była młodsza, 4-letnia siostra. Doświadczenie zdobyte podczas eksperymentów na myszach okazało się być nieocenione.

W kolejnych latach opracowano także metodę oczyszczania szpiku z erytrocytów, co umożliwiło przeprowadzenie zabiegów allogenicznego przeszczepienia szpiku przy dużej niezgodności grup krwi [15]. Przeprowadzono także, u dziewczynki w czwartej remisji ostrej białaczki limfoblastycznej, zabieg autologicznego przeszczepienia szpiku (z oczyszczaniem szpiku in vitro z komórek nowotworowych) [16]. Biorąc pod uwagę oporny na leczenie przebieg choroby kolejna wznowa była tylko kwestią czasu i dzięki temu leczeniu udało się ją odsunąć na ponad dwa lata [8].

Do chwili rozwiązania Zespołu w 1987 r. przeprowadzono jeszcze 8 zabiegów allogenicznego przeszczepienia szpiku, osiągając wieloletnie, utrzymujące się nadal przeżycia u 3 pacjentów. Wynik ten odpowiada osiąganym wówczas na świecie rezultatom [17], a nawet obecnym w tej grupie chorych w zaawansowanych stadiach swoich chorób.

\section{Dalszy rozwój}

Pierwsze sukcesy otworzyły możliwość dalszego rozwoju transplantologii. W końcu lat 80. profesor Kazimierz Sułek (w Klinice Hematologii Wojskowego Instytutu Medycznego) do autotransplantacji zaczął stosować komórki macierzyste pobierane od pacjentów z krwi obwodowej [18], co obecnie stało się standardem postępowania. Metodę tę rozwijał w Katedrze i Klinice Hematologii Śląskiej Akademii Medycznej w Katowicach prof. Jerzy Hołowiecki, stosując mobilizację komórek do krwi obwodowej z zastosowaniem chemioterapii i czynników wzrostu. Jego zespół jako pierwszy dokonał przeszczepienia po pozytywnej selekcji komórek CD34+ [19]. Krew pępowinową jako źródło przeszczepianych komórek macierzystych pierwsi w Polsce wykorzystali w 1995 r. prof. Andrzej Lange i prof. Wiesław W. Jędrzejczak. Miało to miejsce już w 7 lat po pierwszym tego typu zabiegu na świecie [20]. Kolejnym krokiem było przeszczepienie szpiku od dawcy niespokrewnionego. Pierwszego przeszczepienia od dawcy zagranicznego dokonał w lutym 1997 r. prof. Jerzy Hołowiecki [21]. Dzięki rosnącej liczbie potencjalnych dawców pierwsze przeszczepienie od niespokrewnionego dawcy polskiego miało miejsce w tym samym ośrodku w grudniu 1999 r. [22].

\section{Obecnie}

Dzięki trwającemu przez wiele lat systematycznemu wzrostowi liczby wykonywanych zabiegów przeszczepienia udało się uratować wiele tysięcy osób. W roku 2013 (wg danych POLTRANSPLANT [23]) w Polsce wykonano 493 zabiegi allogenicznego przeszczepienia komórek krwiotwórczych (318 od dawców niespokrewnionych i 175 od rodzinnych) oraz 847 procedur autologicznych. Przeprowadzono je w 18 akredytowanych ośrodkach. Najczęściej przeszczepianym materiałem był nie szpik, a macierzyste komórki krwiotwórcze zebrane drogą aferezy (836/847 autoi 416/493 alloprzeszczepienia). Dzięki ciągłemu rozwojowi „szpikodawstwa" coraz więcej polskich pacjentów znajduje dawcę krajowego (54\% w porównaniu z 24\% w 2010 r.). Polacy są też coraz częściej dawcami dla obcokrajowców (479). W Centralnym Rejestrze Niespokrewnionych Potencjalnych Dawców Szpiku i Krwi Pępowinowej 31 grudnia 2013 r. figurowało blisko 540000 potencjalnych dawców.

Pomimo tych dość spektakularnych statystyk rzeczywiste potrzeby są dużo większe. Pamiętając o chlubnej przeszłości, musimy więc dbać o dalszy rozwój.

\section{Podziękowania}

Autor pragnie podziękować prof. Wiesławowi W. Jędrzejczakowi za korektę manuskryptu i udostępnienie zdjęcia prof. Jana Raszka.

\section{Lek., mgr biologii Rafał Machowicz}

Klinika Hematologii, Onkologii i Chorób Wewnętrznych Warszawski Uniwersytet Medyczny ul. Banacha 1a, 02-097 Warszawa e-mail:r.machowicz@wp.pl

Otrzymano: 25 czerwca $2014 \mathrm{r}$.

Przyjęto do druku: 16 lipca 2014 r.

\section{Piśmiennictwo}

1. Major JD. Chirurgia infusoria, placidis cl: virorum dubiis impugnata, cum modesta, ad eadem, responsione. Kilonii : Sumptibus Joh, Lüderwald, imprimeb. Joach. Reumannus, 1667.

2. Seyfarth C. Eine einfache methode zur diagnostichen Entnahme von knochenmark beim lebenden. Arch fur Schiffs-und TropenHygiene Pathol und Ther Exot Krankheiten 1922; 26: 337-341.

3. Arinkin MI. Die Intravitale Untersuchungsmethodik des Knochenmarks. Folia Haematol 1929; 38: 233-240.

4. Parapia L. Trepanning or trephines: a history of bone marrow biopsy. Br J Haematol 2007; 139: 14-19.

5. Migdalska-Romaniuk Z. Leczenie skaz krwotocznych przeszczepieniami szpiku z uwzględnienim metody i wskazań. Pol Arch Med Wewnętrznej 1955; 25: 157-165.

6. Dudley Hart F. Acute lymphatic leukæmia in childhood. Lancet 1938; 231: 1441-1444.

7. Bussel JB. Immune thrombocytopenia (ITP) in children: Initial management. UpToDate 2014, Accessed 18.06.2014.

8. Wiktor-Jedrzejczak W. History of bone marrow transplantation in Poland. Ann Transplant 1996; 1: 15-17. 
9. Thomas ED, Lochte HL, Cannon JH i wsp. Supralethal whole body irradiation and isologous marrow transplantation in man. J. Clin. Invest 1959; 38: 1709-1716.

10. Dausset J. Iso-leuko-antibodies. Acta Haematol 1958; 20: 156-166.

11. Mathé G, Amiel LJ, Schwarzenberg L i wsp. Adoptive immunotherapy of acute leukemia: experimental and clinical results. Cancer Res.1965; 25: 1525-1531.

12. Thomas ED, Buckner CD, Banaji M i wsp. One hundred patients with acute leukemia treated by chemotherapy, total body irradiation, and allogeneic marrow transplantation. Blood 1977; 49: 511-533.

13. Wiktor-Jedrzejczak W, Szczylik C, Pojda Z i wsp. Success of bone marrow transplantation in congenital Diamond-Blackfan anaemia: a case report. Eur J Haematol 1987; 38: 204-206.

14. Wiktor-Jedrzejczak W, Szczylik C, Gónaś P i wsp. Different marrow cell number requirements for the haemopoietic colony formation and the curve of the W/Wv anemia. Experientia 1979; 35: 546-547.

15. Wiktor-Jedrzejczak W, Ratajczak MZ, Szczylik C. Bone marrow transplantation in Polish conditions. Method for removal of red cells from the transplant in the case of major blood group incompatibility. Arch Immunol Ther Exp (Warsz) 1989; 37: 261-267.

16. Jedrzejczak W, Rokicka-Milewska R, Siekierzyński M i wsp. Autologiczny przeszczep szpiku jako próba podtrzymania całkowitej remisji u dziecka chorego na ostrą białaczkę limfoblastyczną. Pediatr Pol 1986; 61: 177-180.
17. Wiktor-JedrzejczakW, Szczylik C, Matej H i wsp. Allogeneic bone marrow transplantation from HLA-identical siblings following conditioning with busulfan and cyclophosphamide. First results. Folia Haematol Int Mag Klin Morphol Blutforsch 1989; 116: 403-408.

18. Sułek K, Kłos M, Dańczak-Ginalska Z i wsp. Pierwsze własne doświadczenia zallo-i autotransplantacją krwiotwórczych komórek macierzystych. Wiad Lek 1990; 43: 1155-1163.

19. Hołowiecki J, Wojnar J, Markiewicz M i wsp. Autologous peripheral blood stem and progenitor cells transplantation as a valid treatment approach in recurrent, refractory lymphoma. Arch Immunol Ther Exp (Warsz) 1995; 43: 191-194.

20. Gluckman E, Broxmeyer HA, Auerbach AD i wsp. Hematopoietic reconstitution in a patient with Fanconi's anemia by means of umbilical-cord blood from an HLA-identical sibling. N Engl J Med 1989; 321: 1174-1178.

21. Holowiecki J, Wojnar J, Krawczyk M i wsp. Bone marrow traansplantations from unrelated donors in leukemias - first successful transplantations confirming the need of development of this method in Poland. Acta Haematol Pol 1998; 29: 527-537.

22. Hołowiecki J. Transplantacja szpiku i komórek krwiotwórczych. Współ Onkol 2000; 4: 195-202.

23. Łęczycka A. Rejestr przeszczepień komórek krwiotwórczych szpiku i krwi obwodowej oraz krwi pępowinowej. Biuletyn Informacyjny POLTRANSPLANT 2014; 22: 55-61. 